\title{
Stabilize Edilmiş İzmir Körfez Bölgesi Doğu Kıyı Şeridi Delta Zeminlerinin XRD ve SEM Analizleri
}

\section{SEM and XRD Analyses of Stabilized East Coastline Delta Soils of Izmir Bay Area}

\author{
Okan Önal $1^{*}$, Çağrıhan Sarıavcı \\ ${ }^{1}$ Dokuz Eylül Üniversitesi Mühendislik Fakültesi İnşaat Mühendisliği Bölümü, İzmir, TÜRKIYE \\ ${ }^{2}$ Dokuz Eylül Üniversitesi Fen Bilimleri Enstitüsü, İzmir, TÜRKiYE \\ Sorumlu Yazar / Corresponding Author*: okan.onal@deu.edu.tr
}

Öz

İzmir Körfezi'nin Batı sahilinde Meles çayı, Arap ve Manda dereleri tarafından tașınmıș yaklașık 3 milyon metreküp kirlenmiş alüvyonel zemin bulunmaktadır. Bu akarsular, $300.000 \mathrm{~m}^{2}$ lik bir deltayı paylașmaktadır. Deltada bulunan alüvyonlar 10 ila $15 \mathrm{~m}$ kalınlığında yüksek su içeriği ve düșük taşıma kapasitesine sahip katmanlardan oluşmaktadır. Meles deltası zaman içerisinde, büyük ölçekli konut inşaat projelerinin yapımının başladığı șehrin doğu sahil șeridi içinde kalmıştır. Geniș bir alan işgal eden ve rekreasyon çalışmaları için bile uygun olmayan bu yumuşak birikintilerinin maliyet etkin bir şekilde stabilizasyonuna ihtiyaç duyulmaktadır. Ayrıca, yolcu gemilerinin İzmir Limanı'na yaklașma kanalını derinleștirmek için delta alanının deniz dibi kısmının da taranması planlanmaktadır. Tarama yolu ile toplanacak kirlenmiş deniz sedimentlerinin depolanması da ayrıca çevresel bir sorun olușturmaktadır. Bu çalıșmada, kireç, çimento ve bunların farklı oranlarda karışımları kullanılarak, Meles Deltası zeminlerinin stabilizasyonu hedeflenmiștir. Optimum katkı oranlarını belirlemek için tek eksenli basınç deneyleri yapılmıştır. Stabilizasyon ürünlerini ve mikro yapıdaki değișiklikleri gözlemlemek için stabilize edilmiș zemin numunelerinde X-ıșını kırınım (XRD) testleri ve taramalı elektron mikroskobu görüntülemesi (SEM) yapılmıștır. X-ışını testlerinde değişik oranlarda stabilizasyon ürünleri tespit edilmiștir. Ayrıca, işlenmemiş ve stabilize edilmiş zemin örneklerinin SEM görüntülerinin karşılaștırılması, mikro yapıda kalsiyum alümina hidratlar ve kalsiyum silika hidratların varlığını ortaya koymuştur.

Anahtar Kelimeler: Zemin İyileștirme, Derin Karıștırma, Kireç-Çimento Karışımları, SEM, XRD

\begin{abstract}
The gulf of İzmir contains 3 million cubic meters of polluted sediments carried by Meles, Arap and Manda rivers. These rivers share the same delta with a surface area approximately $300.000 \mathrm{~m}^{2}$, where 10 to $15 \mathrm{~m}$ thick sediment layers were deposited with high water content and low bearing capacity. The delta is now located along the east coastline of the city, where large scale residential building projects are under construction. These soil deposits that are unsuitable for the establishment of recreational facilities need to be stabilized in a cost-effective way. Besides, the sea bottom portion of the delta area will be dredged in order to deepen the approach channel of the cruise ships to the Izmir Port. The disposal of the contaminated sea sediments has also become an environmental concern. In this study, lime and cement and their mixtures with varying portions were considered as a
\end{abstract}


stabilization agent for soft and contaminated sediments. Unconfined compression tests were conducted in order to determine the optimum additive percentages. X-ray diffraction tests (XRD) and scan electron microscope (SEM) imaging were performed on the stabilized soil specimens in order to observe the cementitious products and changes in the micro structure. In X-ray tests, cementitious by-products were detected in varying ratios. Also, the comparison of SEM images of untreated and stabilized soil specimens reveals the presence of calcium alumina hydrates and calcium silica hydrates in the micro structure.

Keywords: Soil Improvment, Deep Mixing, Lime-Cement Mixtures, SEM, XRD

\section{Giriş}

Katkı maddeleri ile zemini yerinde karıștırarak iyileștirmek özellikle Kuzey ülkeleri olmak üzere birçok ülkede slk uygulanan bir yöntem olarak karşımıza çıkmaktadır. Zemin karıştırma tekniği sığ ve derin karıștırma olarak iki şekilde uygulanabilir. Sığ karıştırma zeminin sınırlı bir derinliğe kadar olan üst kısmının katkı maddeleri katılarak karıştırılması olarak tanımlanabilir. Sı̆̆ karıștırma özellikle yol imalatları gibi aktarılan yüklerin sınırlı olduğu durumlarda tercih edilen ve genellikle bu işe özel olmayan ekipmanlarla inilebilecek derinlikle sınırlı kalan bir uygulamadır. Öte yandan derin karıștırma 30-40 m derinliğe kadar etkili olan ve işe özel ekipmanlarca yapılan bir tekniktir.

Derin karıștırma yöntemi 1986'da ABD'de gerçekleşen ilk uygulamasından bu yana İskandinavya, Japonya ve Kuzey Amerika'da yaygın bir şekilde uygulanmaktadır [1]. Derin karıștırma yönteminde bağlayıcılar zemine kuru ve ıslak olmak üzere iki farklı yöntem ile karıștırılmaktadır [2]. Islak karıștırma prosedürü genellikle yer altı su seviyesinin üzerinde yer alan zemin tabakaları için uygulanır. $\mathrm{Bu}$ şekilde katkı maddelerindeki bağlayıcıların gereksinim duyduğu su enjeksiyon yöntemi ile sağlanmıș olur. Meles Deltası zeminlerinde olduğu gibi yeraltı su seviyesinin altında bulunan, doğal su içeriği yüksek zayıf zeminler için ise kuru karıştırma yöntemi tercih edilir. Kuru karıștırma yönteminde kuru bağlayıcıyı doğrudan zayıf zemin kütlesinin içine enjekte edildiği için hidratasyon sırasında ISı açığa çıkaran sönmemiş kireç gibi bağlayıcıların kullanımına olanak sağlamaktadır. Bu sayede zayıf zeminin su içeriğini düşürerek katılaşmasını sağlamak mümkün olabilmektedir.

İzmir Körfezi Meles Deltasının, Arap ve Manda derelerinin taşıdığı atıklar ve rüsubatın da birikmesi ile $300.000 \mathrm{~m}^{2}$ lik bir alanda 10 ila $15 \mathrm{~m}$ arasında değișen kalınlıklarda yaklaşık 3 milyon $\mathrm{m}^{3}$ artık alüvyonel malzeme içerdiği düșünülmektedir [3]. Yüksek su içeriği ve düșük taşıma gücüne sahip bu çökeller mühendislik özellikleri açısından son derece yetersizidir. Kentin önemli bir noktasında bulunan bu alanın kullanılabilir hale getirilmesi amacıyla İzmir Büyük Şehir Belediyesi tarafından derin karıștırma yöntemi ile zemin iyileștirmesi yapılması öngörülmüștür.

$\mathrm{Bu}$ çalışmada yerinde derin karıştırma uygulamasının performansının öngörülmesi amacıyla X-ışını kırım (XRD) ve taramalı elektron mikroskopu (SEM) analizleri ile zeminin bünyesindeki değişimlerin izlenmesi amaçlanmıştır. Literatürdeki diğer çalışmalara benzer bir șekilde kireç, çimento ve bu malzemelerin karıșımları kimyasal bağlayıcı olarak farklı oranlarda kullanılmıştır. Bu amaçla zemin örnekleri alınmış, sınıflandırma deneyleri gerçekleștirilmiş, derin karıştırma tekniğine uygun șekilde zemin örnekleri hazırlanmış ve farklı kireç ve çimento katkı oranları ile stabilizasyon gerçekleștirilmiștir. Daha sonra, sahada iyileștirme uygulanacak bölgedeki ortam özelliklerini temsil edecek şekilde örnekler kür edilmiștir. Kür edilmiș örneklerin mühendislik parametreleri tek eksenli basınç deneyi ile belirlendikten sonra zemin bünyesinde oluşan değișimlerin X-ıșını kırım (XRD) ve taramalı elektron mikroskopu (SEM) analizleri ile takibi hedeflenmiștir.

\section{Literatür Taraması}

Kireç, ekonomik olması ve uygulama kolaylığı bakımından alüvyonel birikimlerin stabilizasyonunda en çok tercih edilen katkı maddesi olmuştur. Birçok çalışmada kirecin ince daneli zeminlerin mühendislik özelliklerini iyileștirdiği kanıtlanmıştır [4, 5]. Daha sonraları, çimentonun da alüvyonel zeminlerin stabilizasyonunda kireç ile beraber kullanılabileceği ve bu sayede daha yüksek dayanımlar elde edilebileceği öne sürülmüştür [6-8].

Boardman vd. [9], kirecin sönmüş [kalsiyum hidroksit $\left.\left(\mathrm{Ca}(\mathrm{OH})_{2}\right)\right]$ veya sönmemiş [kalsiyum 
DEU FMD 21(63), 967-978, 2019

oksit (CaO)] formda kil zeminlerin fiziksel özelliklerini iyileştirmede yüzyıllardır kullanıldığını bildirmiştir. Sönmemiş kireç, zemine karıştırıldığında zemin boşluklarındaki su ile temas etmesiyle beraber yüksek ekzotermik bir hidrasyon reaksiyonu başlar. $\mathrm{Bu}$ reaksiyon için harcanan su, zemin bünyesinden alındığı için zemin katılaşma sonucu daha iyi bir işlenebilirliğe ulaşır. Buna ek olarak zeminin pH'ında da bir artış olur. Hidrate olmuş kireç daha sonra zemindeki puzolanik malzemeler ve geriye kalan su ile reaksiyona girer ve uzun dönemde dayanım sağlayan kalsiyum silikat hidratın (CSH) olușmasını sağlar [2].

Kireç gibi çimento da hidrolik tip bir stabilizasyon ajanıdır. Bergado vd. [10] çimento ile kil minerali arasına iki büyük kimyasal reaksiyon olduğunu söylemektedir. Bunlardan birincisi, çimento ve zemindeki suyun birincil hidrasyon reaksiyonu iken, diğeri çimento tarafından salınan kireç ile kil mineralleri arasındaki puzolanik reaksiyonlardır. Stabilizasyon ișlemi sırasında zemin danelerinin bağlanması, hidrolik reaksiyonlar boyunca oluşan bağlayıcı jeller olan kalsiyum silikat hidrat $(\mathrm{CSH})$ ve kalsiyum alüminat hidrat $(\mathrm{CAH})$ bileşikleri tarafından yönetilir.

Timotey vd. [2] organik madde içeriği yüksek zeminlerin katkı maddeleri ile stabilizasyonu konusunda çalıșmıșlardır. Çalıșmalarında, organik zeminlerin stabilizasyonunda kalsiyum hidroksitin humik asit ile zemin danelerini kaplayan çözünmez ürünler oluşturduğunu belirlemişlerdir. Yüksek seviyede organik içeriğe sahip zeminlerin stabilizasyonu konusunda Hebib ve Farrell [11] ve Hernandez-Martinez ve Al-Tabbaa [12] çalışmalar yürütmüşlerdir. Bu araştırmacılar özellikle stabilizasyon sürecini ve iyileștirilmiş zemin parçalarını elektron mikroskop ile incelemişlerdir. Çalışmaları sonucunda hidrasyon sonucu ortaya çlkan bağlayıcı karakterdeki bileșikler ile turba türü zeminde bulunan organik maddeler arasında neredeyse hiç etkileşim olmadığını belirlemişlerdir.

Söz konusu araştırmaların sonuçları Axelsson vd.'nin [13] yaptığı çalıșmalar ile beraber değerlendirildiğinde, eșik bir katkı oranının altında zeminde hiçbir iyileşme olmadığı görülmektedir. Zemine eklenen katkı, eşik seviyesine kadar organik zemindeki mevcut asitleri nötralize etmek için harcanmaktadır. Ancak bu eşik seviyesi aşıldıktan sonra kalan katkı maddesi zemin bünyesi ile reaksiyona girebilmekte ve ortamın pH'ının artmasına neden olabilmektedir.

Dunkirk limanından çkartılan tarama malzemelerinin kıvam limitlerinde çimento ve kireç katkısının etkisi Wang vd. [14] tarafından araştırılmıştır. Ayrıca Grubb vd. [15] tarafından iyileștirilmiș tarama malzemelerinin mukavemet özellikleri tek eksenli basınç deneyleri ile belirlenmiștir. Bu çalışma yüksek su içeriğine sahip tarama malzemelerin doğru karışım oranları ile stabilize edilebileceğini göstermiștir. Miura vd. [16] derin zemin karıştırma uygulamaları için laboratuvar deneyleri gerçekleştirmiştir. Araştırmalarında özellikle bağlayıcı oranı ve tek eksenli basınç dayanımlarına odaklanarak Ariake-Saga ve Hong Kong killeri üzerinde çalışmışlardır.

Sıkıştırılmış zemin kireç karışımlarında meydana gelen fiziksel ve kimyasal reaksiyonların, zeminlerin hidrolik ve mekanik özelliklerine etkisini araștırmak üzere Di Sante vd. [17] bir araştırma programı düzenlemiştir. Zemin kireç reaksiyonlarının etkileri SEM görüntüleri ile takip edilmiș ve ayrıca $\mathrm{pH}$ değerlerindeki değișimler izlenmiștir. Çalışmalarında doğal durumdaki zeminde, kil daneleri lamine bir halde olduğu görülmüștür. Öte yandan, kireç ile karıştırılan ve 24 saat kür edilen örneğin SEM grafikleri zemin yapısının oldukça gözenekli bir yapıya dönüștügünü belirlemişlerdir. Ancak iyileștirilmiş zemin numunesinin iki farklı bölgesinde gerçekleștirilen XRD analizleri karşılaştırıldığında, benzer yapıların farklı oranlarda ortaya çıktığı görülmüștür. Bu da araştırmacıları kireç reaksiyonlarının karışımda uniform bir şekilde gerçekleşmediği sonucuna götürmüștür. Tepkime sonu ortaya çıan bağlayıcı yapıların düzensiz dağılımı zemin kireç reaksiyonları için suyun gerekliliğini ortaya koymuştur. $\mathrm{Bu}$ çalışmada analiz edilen örneklerin \%20 doygunluk durumuna tekabül eden yaklaşık \%20 su içeriğine sahip örnekler olmasından dolayı kısmen suya doygun olan gözeneklerin düzensiz bir dağılımın oluşmasına yol açtığı düşünülmüştür ve zemin kireç reaksiyonlarının homojen dağılması için ortamdaki suyun varlığının önemi ortaya çlkmıștır.

Rajasekaran vd. [18] denizsel ortamda çökelmiş killerin iyileştirme sonrası minerolojik değișimleri üzerine çalıșmışlardır. Açık deniz yapılarına gelen dalga etkilerine karşı temel sistemlerinin desteklemek üzere zemin 
DEU FMD 21(63), 967-978, 2019

iyileștirme ihtiyacı ortaya çıkmıștır. Hindistan'ın Doğu sahil bölgelerinden alınan zeminler kireç ve sodium hidroksit kimyasalları kullanılarak iyileștirilmişlerdir. Kireç ile stabilize edilmiş tüm örneklerde farklı boyutlardaki agrega oluşumları SEM görüntüleri ile gözlenmiş ve ayrıca XRD analiz sonuçları ile kalsiyum silikat hidrat ve kalsiyum alümina hidrat gruplarının gelişimi ortaya konulmuştur.

Dash ve Hussain, [19] 2011'de yaptığı çalıșmada kireç katkısının silika açısından zengin yüksek ve düșük plastisiteli killerde etkisini SEM ve XRD analizleri ile ortaya koymuştur. Her iki analizde de mikro yapıdaki çimentolanma ürünleri belirlenmiş ve bu tür zeminlerde optimum kireç oranından sonra oluşan jel matrislerin plastisiteyi arttırdığını belirlemiştir.

\section{Materyal ve Metot}

\subsection{Dip Tarama Malzemesi ve Numune Alımı}

Derin karıștırma yöntemi ile stabilize edilmek istenen alan șehrin liman bölgesine yakın Halkapınar/Konak'ta bulunmaktadır. Tarama malzemesi Meles çayının içinden ekskavatörün kepçesi ile taranarak, su içerisinden çıkartılmış ve uygun bir alana serilmiş ve kapaklı bidonlar içerisine alınmıştır. Zemininin örneklenme şeklinden dolayı numunelerin doğal su içerikleri tespit edilememiştir.

Kurutma metodunun Atterberg limitlerine olan etkisini gözlemlemek için, biri oda sıcaklığı olmak üzere örnekler dört farklı sıcaklıkta kurutulmuștur. $\quad \mathrm{Bu}$ șekilde örneklerin Birleștirilmiș Zemin Sınıflandırmasına göre organik olarak nitelenip nitelenmeyeceği belirlenmiștir. Sonuçlardaki ihmal edilebilir farklardan dolayı tüm örnekler $105^{\circ} \mathrm{C}$ da kurutulmuș ve çeneli kırıcı ile ögütülerek toz hale getirilmiş ve saklama kutularında muhafaza edilmiştir.

\subsection{Bağlayıcılar}

Hidrolik veya hidrolik olmayan bağlayıcılar zemin iyileştirme işlerinde kullanılabilir. Hidrolik bağlayıcılar su ile temas ettiğinde kür olurken, hidrolik olmayan bağlayıcılar kür olmak için bir katalizöre (çoğunlukla hava) ihtiyaç duyarlar. Jose [20], kireç ve çimentonun deniz çökelleri için son derece etkili bağlayıcılar olduklarını söylemiştir. Bu çalışmada katkı maddesi seçimi iyileştirilecek zeminin yerindeki durumu göz önünde bulundurularak hidrolik kireç ve çimento olarak seçilmiştir. Bu çalışmada kullanılan kireç yüksek kalsiyum içerikli sönmemiș kireç (CaO) ve TS EN 197-1 (2012) standartlarına uygun CEM-I 42.5 R türü Portlant çimentosudur.

\subsection{Atterberg Limitleri}

Zeminlerin plastisitesi dört faklı kurutma koșulu için belirlenmiştir. Bu koşullar, havada kurutma $\left(25^{\circ} \mathrm{C}\right), 60^{\circ} \mathrm{C}, 86^{\circ} \mathrm{C}$ ve $105^{\circ} \mathrm{C}^{\prime}$ dır. Bu şekilde her kurutma sıcaklığı için likit limit değeri karşılaştırılarak kurutma sıcaklığının Atterberg limitlerine olan etkisi incelenmiștir. Likit limit belirlenmesinde düşen koni metodu kullanılırken plastik limit için elde yoğurma metodu kullanılmıștır.

\subsection{Organik Madde İçeriği}

Zemin iyileştirme çalışmalarında zeminin organik içeriği, kullanılacak bağlayıcının dozajının belirlenmesinde oldukça büyük önem taşımaktadır. Bağlayıcı maddeler, zemin içinde önce organik maddeler ile reaksiyona girdikleri için, zeminin stabilizasyonu için kalan bağlayıcı miktarı önemlidir. Yüksek organik içeriğe sahip zeminlerde pH'ın yükselebilmesi için yüksek miktarda kireç kullanılması gerekebilmektedir [21].

Bu sebeplerden ötürü, zeminin organik madde tayini için $440^{\circ} \mathrm{C}^{\prime}$ de yakılarak ASTM D297407a'ya uygun olacak şekilde gerçekleştirilmiştir.

\subsection{Zemin Sınıflandırması}

Zemin sınıflandırmasında Birleștirilmiş Zemin Sinıflandırma Sistemi (ASTM D2487-11) kullanılmıștır. Atterberg limitlerindeki değişim incelendikten sonra, $105^{\circ} \mathrm{C}^{\prime}$ da kurutulmuş örneklerin likit limit ve plastik limit değerleri kullanılarak sınıflandırma yapılmıștır.

\subsection{Tek Eksenli Basınç Deneyleri}

Örneklerin tek eksenli basınç dayanımları ASTM D2166-132'ye uygun olarak belirlenmiştir. Yüklemeler esnasında eksantrik yükleme yapılmamasına dikkat edilmiștir. Ayrıca örneklerin direnajsız yüklenmesi ve yükleme esnasında kurumamaları için göçme yüküne en fazla 15 dakika içinde ulaşacak yükleme hızı seçilmiștir.

\subsection{Taramalı Elektron Mikroskopu (SEM) Analizleri}

$\mathrm{Bu}$ çalışma kapsamında zemin bünyesinde meydana gelen değișimleri izlenebilmesi için SEM analizleri gerçekleștirilmiştir. Testler Dokuz Eylül Üniversitesi Metalürji ve Malzeme 
DEU FMD 21(63), 967-978, 2019

Mühendisliği Bölümü Elektron Mikroskopi Laboratuvarında bulunan $10 \mathrm{kV}$ gücündeki JEOL-JSM6060 Taramalı Elektron Mikroskopunda yapılmıştır (Şekil 1). Büyütme ilk inceleme için mümkün olan en düşük seviyeye ayarlanmıștır. Daha sonra 5000 kat ve 10000 kat yaklaştırma seviyeleri kullanılmıştır.

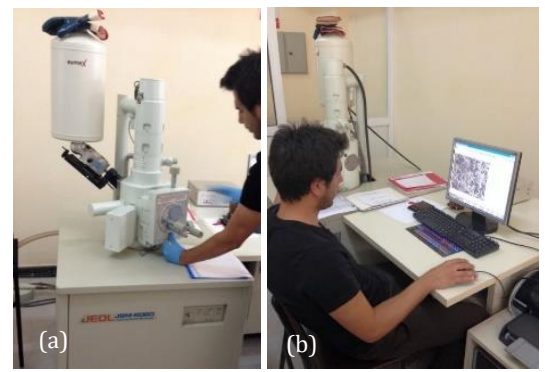

Şekil 1. SEM deney ekipmanı

SEM analizleri için katkı karıștırılmamış zemin ve mukavemet deneyleri için hazırlanan örneklerle aynı nitelikte ve kür süresinde ortalama $5 \mathrm{~mm}$ boyutlara sahip kübik şekilde örnekler kullanılmıștır (Sekil 2a). Hazırlanan örnekler üzerlerinde toz ve kalıntılardan arındırılarak vakumlanmışlardır. İletken çift taraflı karbon bant yardımıyla örnek tutucular üzerine yapıştırılmıştır (Şekil 2b ve 42).

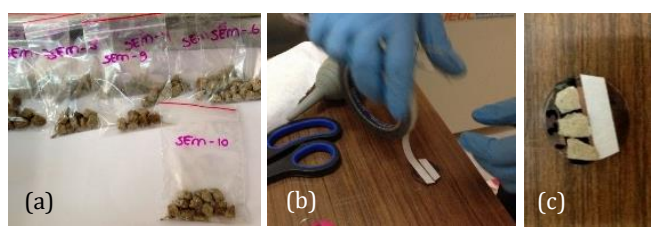

Şekil 2. Hazırlanan örnekler (a) SEM deneyleri için örneklerin sabitlenmesi $(b, c)$

SEM ile görüntülemeye geçmeden önce örnekler iletken ince bir tabaka altın ile kaplanmıștır. Kaplama ișleminde Quorum TechnologiesSc7620 Mini kaplama aleti kullanılmıștır (Şekil 3).
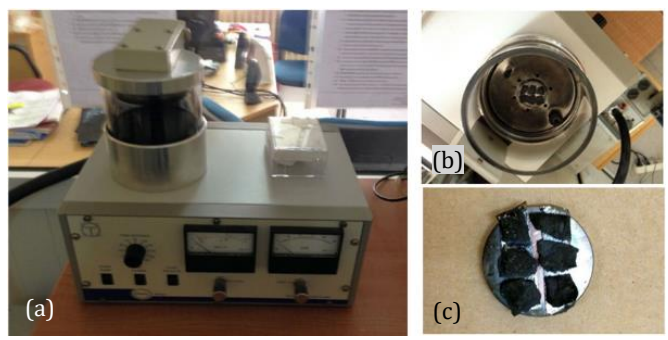

Șekil 3. Altın kaplama ekipmanı (a), kaplama işlemi (b) ve kaplanmış örnekler (c)

\subsection{X-Işını Kırınım (XRD) Deneyleri}

X-Işını kırınım mikro-yapısal analizi (XRD) İzmir Yüksek Teknoloji Enstitüsü Merkez Malzeme Araștırma Laboratuvarında yapılmıștır. Bu analiz ile hem doğal zeminin hem de stabilize edilmiş zemin örneklerinin kimyasal içerikleri ve kristalografik yapılarının belirlenmesi amaçlanmıştır.

XRD deneyleri ile pozolonik reaksiyonlar sonucu ortaya çıkan bileșenlerin zaman içerisinde değişiminin tespit edilmesi amaçlanmıștır. $\mathrm{Bu}$ araștırmada Philips X'Pert Pro Diffractometer deney ekipmanı kullanılmıștır.

Mukavemet deneyleri ile aynı nitelikte hazırlanan örnekler toz hale getirilerek 200 numaralı elekten elenmiştir. XRD deneyi için gerekli numuneler ağzı kapalı hava geçirmeyen plastik torbalarda muhafaza edilmiştir. XRD grafikleri $45 \mathrm{kV}$ ve $40 \mathrm{~mA}$ ile $\mathrm{Cu}$ ıșınımları ile alınmıştır. Tarama işlemi $5^{\circ}$ den $80^{\circ}$ ye kadar $0.033^{\circ}$ lik adımlarla yapılmıștır.

\section{9. Örneklerin Hazırlanması ve Bağlayıcılık Oranları}

Laboratuvar örnekleri bu çalışmada sahada uygulanacak derin karıștırma uygulaması ile uyumlu olacak şeklide hazırlanmıştır. Bu maksatla zemin bağlayıcı ile karıștırılırken yerindeki su içeriği ve birim hacim ağırlığı dikkate alınmış ve numuneler kalıplanırken sıkıștırma ișlemi uygulanmamıștır. Örnekler PVC borudan oluşturulan kalıplara hafifçe vurma ve șişleme yoluyla yerleștirilmiștir. Hazırlanan örnekler suya batık konumda farklı zaman periyotları için kür edilmiştir. Uygulanan örnek hazırlama prosedürü ile homojen, boşluksuz ve tekrar edilebilir örnekler hazırlanabilmiştir. Bu çalıșmada $\% 2, \% 4, \% 8$ kireç, $\% 4, \% 8$ çimento ve $\% 2$ kireç+\%2 çimento, $\% 4$ kireç+\%4 çimento ve $\% 8$ kireç+\%8 çimento olmak üzere 8 değişik oranda bağlayıcı kullanılmıștır. Karıșım oranları malzemelerin kuru ağırlıkça oranlarını içermektedir.

Örnekler hazırlanırken öncelikle öğütülmüş durumdaki zemin likit limitine getirilerek 2 saat bekletilmiştir. Filtre kağıtları şerit şeklinde kesilerek kalıp içine yerleştirilmiş ve kalıbın altı șeffaf film ile sarılmıș ve film 0-ringler ile sabitlenmiştir. Daha önce likit limit su içeriğine ulaştırılan örnekler bağlayıcı katılarak karıștırılmış ve kalıpların içerisine yerleştirilmiştir. Karıșımlar üç katman olacak şekilde kalıplara yerleştirilmiştir. Her katman yerleștirildikten sonra karıșım 30 
DEU FMD 21(63), 967-978, 2019

kez hafif darbe ile yayma, 15 kez şișleme ve 30 kez tekrar darbe vurma işlemine tabii tutulmuştur. Her katman için aynı işlem tekrar edilmiştir. Tekrar edilebilir olması açısından darbe ile yayma Casagrande test düzeneğinin alt tablası kullanılarak yapılmıştır. Kalıplar tam olarak doldurulduktan sonra 0-ringler ve şeffaf filmler çıkartılmış ve kalıp cidarları kullanılarak örneklerin üst ve alt kısımları spatula ile tesviye edilmiştir. Dairesel filtre kağıtları kesilerek tesviye edilen yüzeylere konulmuștur. $\mathrm{Bu}$ şekilde kalıp iç cidarındaki düșey filtre kağıtları ve üst ve alt dairesel filtre kağıtları ile örneğin dışarıdan su alabilmesini sağlayacak bir sistem oluşturmuştur. Bu şekilde her karışım oranı ve kür süresi için 2 adet örnek hazırlanmıştır.

\subsection{Kür Koşulları}

Kür süresi hem kısa hem de uzun dönem stabilizasyon davranışını gözlemlemek için 7, 14, 28 ve 56 gün olarak belirlenmiștir. Numuneler kalıplara yerleștirildikten sonra $23^{\circ} \mathrm{C}$ sabit sıcaklıktaki kür banyosuna bırakılmışlardır. Örneklerin bünyelerine aldıkları su ile şişmelerini engellemek için kalıpların üst ve altına koyulan metal plakaların üstüne basınç ağırlık koyulmuștur. Kür süreleri tamamlanan örnekler banyodan alınmıș, PVC kalıplardan çıkartılmış, boyutları ve ağırlıkları ölçülmüş, deneyleri tamamlandıktan sonra ise su içerikleri belirlenmiștir.

\section{Bulgular ve Tartışma}

\subsection{Tarama Malzemesinin Sınıflandırması}

Alınan örnekler Birleștirilmiş Zemin Sınıflandırmasına göre düşük plastisiteli kil (CL) olarak adlandırılmıștır. Görsel olarak örneklerin koyu renkli ve kokulu oldukları ve hava ile temas eden yüzeylerinin açık kahverengiye döndüğü izlenmiştir. Yapılan organik madde içeriği deneyinde organik madde içeriği \%11 olarak bulunmuştur. $\mathrm{Bu}$ yüzden örneklerin kurutulma sıcaklığının Atterberg limitlerine etkisi incelenmiştir. $25^{\circ} \mathrm{C}^{\prime} \mathrm{da}$ ve $105^{\circ} \mathrm{C}$ 'da kurutulan örneklerin likit limitleri sırasıyla $\% 47.1$ ve $\% 45.2$ olarak belirlenirken, plastik limitleri ise $\% 26.4$ ve $\% 24.8$ olarak tespit edilmiștir. Örnekleri kurutma sıcaklığının Atterberg limitleri üzerindeki etkisi ihmal edilebilir seviyelerde olduğu görülerek tüm örnekler etüvde $105^{\circ} \mathrm{C}$ 'de kurutulmuş ve öğütülerek toz haline getirilmiştir.

\subsection{Tek Eksenli Basınç Deneyleri}

$\mathrm{Bu}$ çalışma için hazırlanan farklı karışım oranlarına sahip örneklerin faklı kür sürelerine karşılık gelen SBD sonuçları Şekil 4'de gösterilmiştir. Toplamda 8 bağlayıcı oranına karşılık 4 farklı kür süresi ve her kür süresi için iki örnek olmak üzere 64 örnek deneye tabi tutulmuştur. Deney sonuçları Şekil 7'de toplu olarak bar grafikler ile ifade edilmiștir. Șekil incelendiğinde artan bağlayıcı oranı ve artan kür süresi ile mukavemetin arttı̆̆ı, en yüksek basınç dayanımının $500 \mathrm{kPa}$ ile $\% 8$ kireç ve $\% 8$ çimento karışımı ile stabilize edilen örneğin 56 günlük dayanımı olduğu, çimento içeren örneklerin daha kısa sürede dayanım kazanırken kireç içeren örneklerin daha uzun bir sürede fakat artan bir șekilde dayanım kazandığ bağlayıcı oranlarında dayanımın zaman içerisinde gelişemediği görülmüştür.

Ayrıca \%4 kireç veya \%4 çimento ya karşılık \%2 çimento +\%2 kireç gibi eşit toplam karışım oranına sahip örneklerde kireçli karışımların daha yüksek performansa sahip olduğu ve dayanım trendinin zaman içerisinde yükseliş gösterdiği görülmüştür. Bu çalışma kapsamında olmayan, katkı oranlarının tek eksenli basınç dayanımları üzerine etkisi Sarıvcı [22] tarafından değerlendirilmiştir.

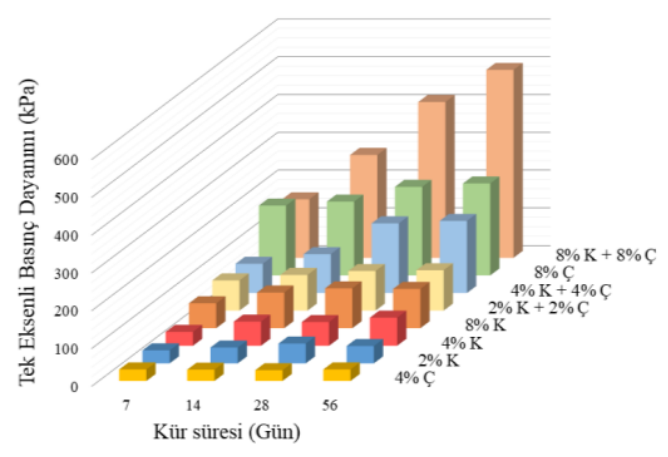

Şekil 4. Tüm örneklere ait tek eksenli basınç deney sonuçları (K: Kireç, Ç: Çimento)

\subsection{Taramalı Elektron Mikroskopu (SEM) Mikrografikleri}

Katkı maddeleri ile reaksiyon sonucu zemin iskeletinde meydana gelen değişimler SEM görüntüleri ile izlenmiștir. Tek eksenli basınç deney sonuçları göz önüne alınarak, zemin iskeletindeki mikro değişimleri daha iyi takip edebilmek için SEM analizlerinde sadece kireç ve çimento-kireç karışımları ile stabilize edilmiş örnekler üzerinde çalışılmıştır. Katkı maddeleri ile işlenmemiş ham durumdaki zemin örneğinin görüntüleri referans teşkil etmesi amacıyla 5000 ve 10000 kat yaklaştırma ile görüntülenmiştir (Şekil 5a ve 5b). 


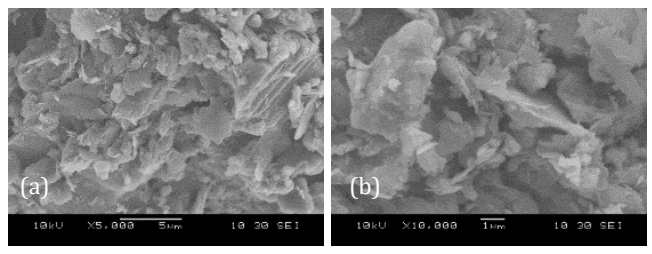

Şekil 5. Doğal zemin örneğinin farklı yaklaştırmalardaki SEM görüntüsü

Görüntüler incelendiğinde ham durumdaki zeminin yapraksı birimlerden oluştuğu ve süreksiz bir yapıya sahip olduğu ve daneler arası boşlukların açlkça görünebildiği gözlenebilir. Şekil 6'da \%2, \%4 ve \%8 kireç katkısının 7 günlük kür süresindeki etkisi görülmektedir. Her katkı oranı için görüntüler 5000 ve 10000 yaklaştırma ile alınmıştır. Kireç katkılı örneklerde \%2 kireç katkılı örnekler hariç zemin iskeletinin ayrık dane yapısından daha bütünleşmiş bir yapıya doğru geçtiği görülmektedir. Çimentolanma reaksiyonları mevcut daneleri daha bağlı bir yapıya taşımıştır. Bu durum Şekil $6 \mathrm{~b}$ ve c'de görülebilmektedir. Çimentolanma ürünlerini 10000 yaklaştırma ile çekilmiș \%8 kireç katkısına sahip zemin örneğinde izlemek mümkündür (Şekil 6c). Bu tür yapıların miktarı kür süresi arttıkça artmıştır. Bu da \%8 kireç ile iyileștirilmiş örneklerdeki tek eksenli basınç dayanım artışlarını açıklamaktadır.

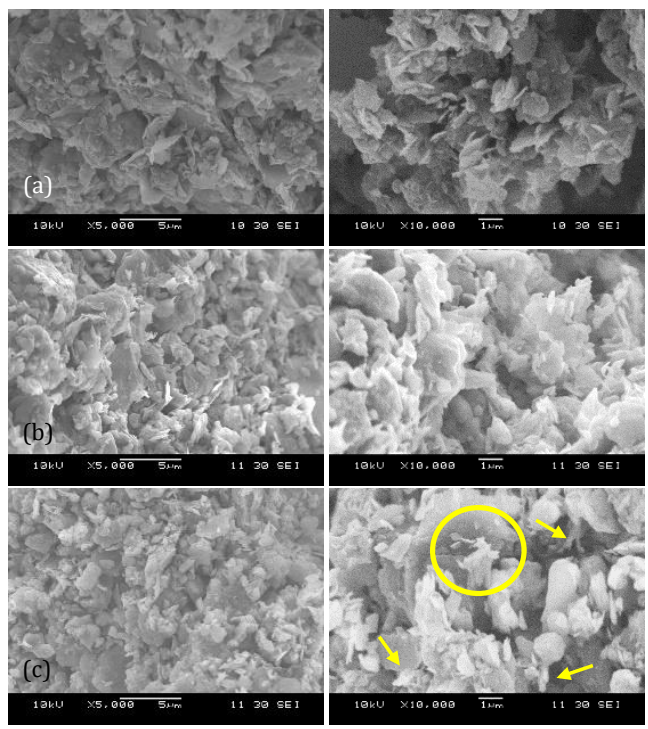

Şekil 6. 7 gün kür süresine sahip (a) 2\%, (b) 4\%, (c) 8\% kireç ile iyileştirilmiş zeminin SEM görüntüleri
Öte yandan \%2 kireç katkısına karşılık gelen karışım (Şekil 6a) işlenmemiş zemin (Şekil 5) ile kıyaslandığında zemin yapısında neredeyse hiçbir değişim gözlenememiştir. Bu durum eklenen kireç miktarının stabilizasyonu bașlatmak için gerekli eșik seviyesinin altında kaldığından dolayı gözlendiği düşünülmüştür. $\mathrm{Bu}$ olgu tek eksenli basınç dayanım sonuçları ile de paralellik göstermiştir. \%2 kireç katkısının 7 günlük tek eksenli basınç dayanımı dikkate alındığında stabilizasyon reaksiyonlarının henüz gelişmediği görülebilir.

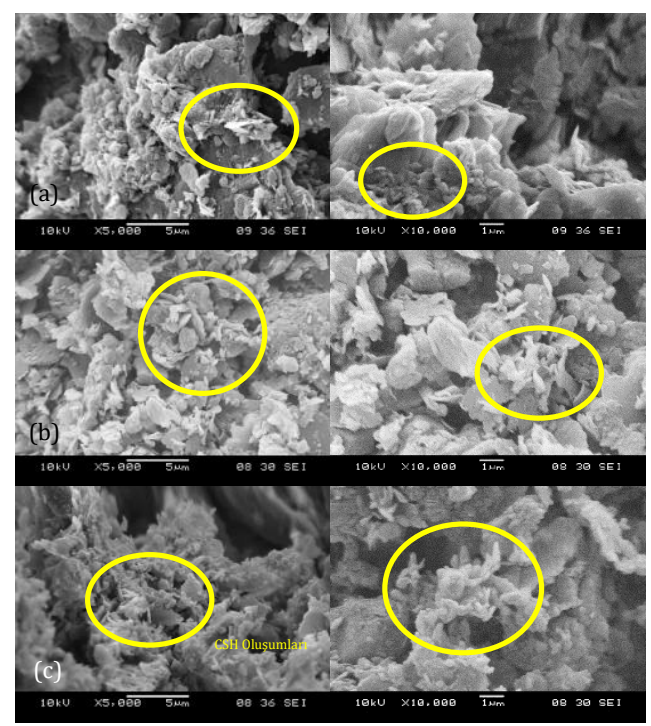

Şekil 7. 28 gün kür süresine sahip (a) 2\%, (b) 4\%, (c) 8\% kireç ile iyileștirilmiş zeminin SEM görüntüleri

Șekil 7'da kireç stabilizasyonun zemin yapısında meydana getirdiği değișimler çok daha iyi bir şekilde izlenebilmektedir. Bu şekilde aynı kireç oranlarına sahip örneklerin 28 günlük kür süresi sonundaki durumları gösterilmiştir.

28 günlük örneklerde ince danelerin etrafını kaplayan ve daha iri daneler şekline getiren jel formundaki Kalsiyum Silikat Hidrat (CSH)'ın yanında Kalsiyum Aliuminat Hidrat (CAH) da açık bir şekilde görülmüştür. CSH kristallerine özellikle \%8 kireç oranına sahip örneklerde daha sık rastlanmıştır.

Şekil 8 ve 9'de kireç ve çimento ile stabilize edilmiş örneklerin 7 ve 28 günlük kür sürelerine karşıllk gelen SEM görüntüleri görülebilir. Daha önce gözlenen sadece kireçli örneklerdeki yapılara ek olarak kristal oluşumlarının da özellikle 28 günlük kür süresine sahip \%8 kireç 
ve $\% 8$ çimentolu örneklerde izlenebildiği görülebilir.

Şekil 10 incelendiğinde çimento katkısının zeminin boşluk yapısını azalttığı ve daha rijit bir kütleye dönüştürdügü bunun da zeminin kayma dayanımına katkı sağladığı görülebilmektedir. Özellikle Şekil 10c'de görülen iğnemsi formdaki çimentolanma ürünleri $\% 8$ kireç ve $\% 8$ çimento ile iyileştirilmiş zeminin yüksek tek eksenli basınç dayanımını açıklamaktadır.

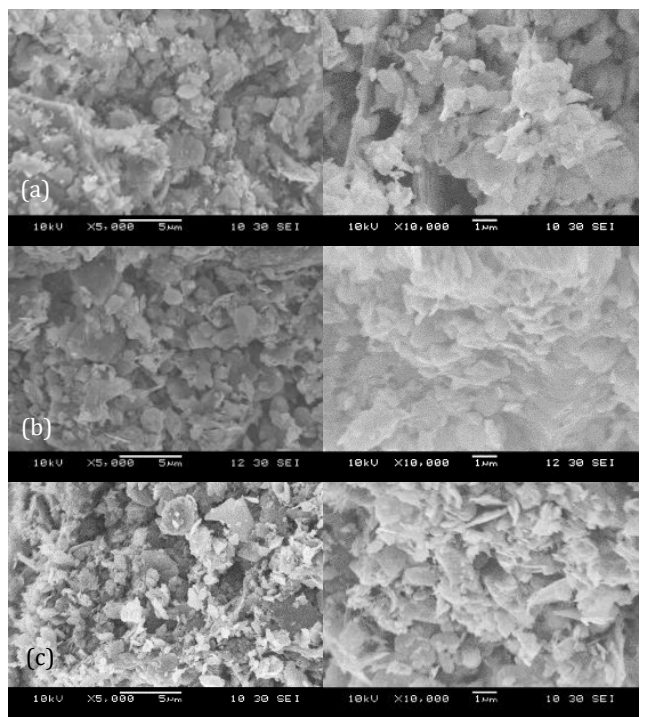

Şekil 8. Kireç ve çimento karışımları ile iyileștirilmiș 7 gün kür süresine sahip zeminin ((a) $2 \%+2 \%$, (b) $4 \%+4 \%$, (c) $8 \%+8 \%$ ) SEM görüntüleri

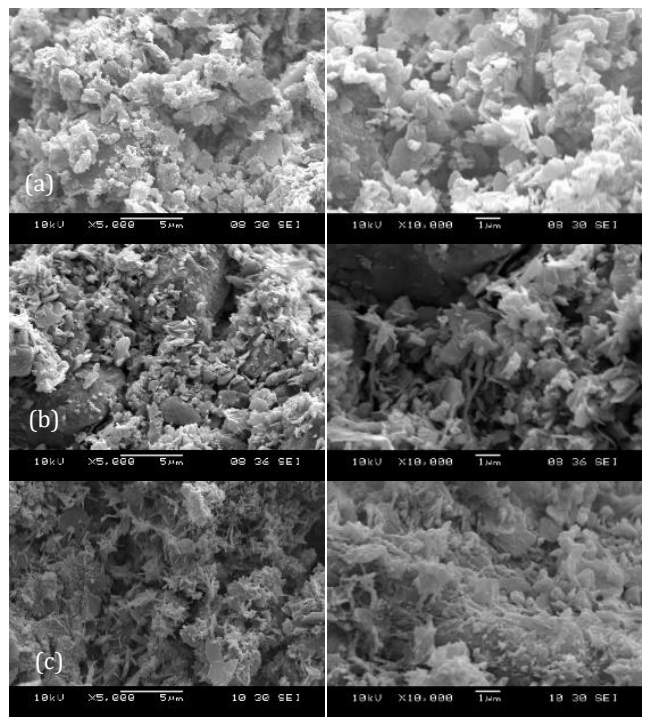

Şekil 9. Kireç ve çimento karışımları ile iyileștirilmiș 28 gün kür süresine sahip zeminin ((a) $2 \%+2 \%$, (b) $4 \%+4 \%$, (c) $8 \%+8 \%$ ) SEM görüntüleri

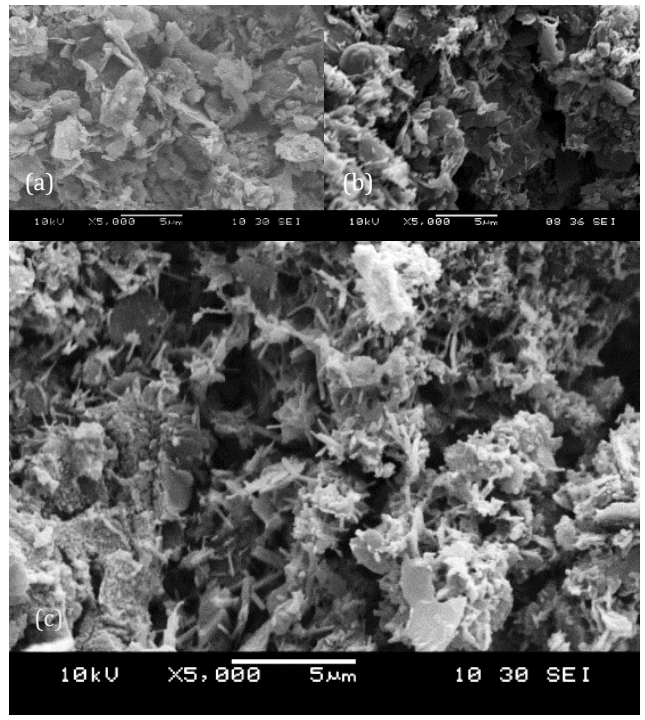

Şekil 10. İyileştirilmemiş (a) ve kireç çimento karıșımları ile iyileştirilmiş (b) $4 \%+4 \%$ ve (c) $8 \%+8 \%$ zeminin 28 gün kür sonucu SEM görüntüleri

Șekil 10'de gözlenebilen reaksiyon ürünleri dikkate alındığında boşluk yapısındaki azalmadan kaynaklanan stabilizasyon daha belirgin bir şekilde izlenmektedir. Çimentolanma ürünlerinin olușumu ișlenmemiș durum ile (Şekil 10a) kristal yapıların gözlendiği 
DEU FMD 21(63), 967-978, 2019

iyileștirilmiș durum (Șekil 10c) kıyaslandığında çok daha iyi görülmektedir.

Elde edilen SEM görüntülerine bakıldığında, iyileșmiş zeminlerin homojen bloklardan oluştuğu söylenebilir. Bu sonuca bakarak bu çalışmada kullanılan örnek oluşturma tekniğinin başarılı olduğu söylenebilir. Bir başka önemli nokta ise çimentolanma reaksiyonları için gerekli nemin örneklerin suya batık olarak kür edilmesi ile karșılandığı ve bu süreçte yerleștirilen filtre kağıtlarının önemli bir işlevi olduğudur.

$\mathrm{Bu}$ çalıșmadaki bir bașka sonuç ise SEM görüntüleri ile dayanım deneylerinden elde edilen sonuçların paralellik gösterdiğidir. Karışım oranı ve kür süresine bağlı olarak yüksek dayanıma sahip örneklerde hidrasyon reaksiyonları sonucu oluşan bileșenlere daha fazla rastlanmıştır.

\subsection{X-Ișını Kırınım (XRD) Deney Sonuçları}

SEM analizlerinde olduğu gibi XRD analizlerinde de sadece kireç ve çimento-kireç karışımları ile stabilize edilmiş örnekler üzerinde çalıșılmıștır. Buna ek olarak tarama malzemesinin doğal durumu da XRD deneyi ile incelenmiștir. Elde edilen kırınım verilerini işlemek için, "Match! Phase Identification from Powder Diffraction" yazılımı kullanılmıștır. Şekil 11'da doğal durumdaki tarama malzemesinin X-ışını kırınım grafiği görülmektedir. Bu șekilde görüldüğü gibi tarama malzemesinin ana yapısının muscovite ve cuspidine'den oluştuğu söylenebilir. Üçüncü ve dördüncü ana mineral bileșenleri ise sırasıyla graphite ve calcite olarak belirlenmiștir. Diagrama bakıldığında hatırı sayılır bir oranda quartz'ında var olduğu görülmektedir. Adı geçen minerallerin formülasyonu ve oranları Şekil 11 'da gösterilmiștir ve kırınım diyagramının altında renkli barlar ile pik noktalar ve bileșenler işaretlenmiştir. Kırınım grafiğinde bazı kirletici metallere de rastlanılmış fakat çok düşük oranlarda oldukları için dahil edilmemișlerdir.

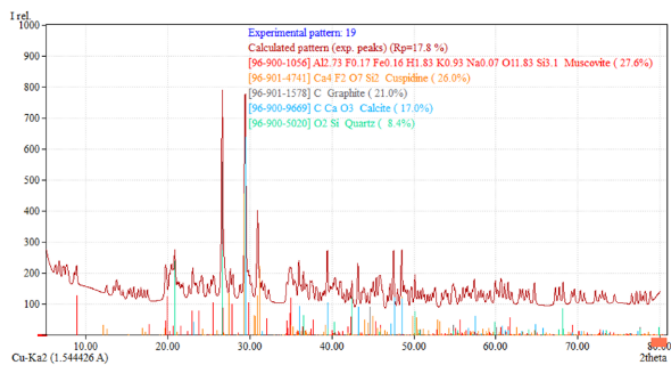

Şekil 11. Doğal tarama malzemesinin X-ışını kırınım grafiği
Şekil 12'den Şekil 15'e kadar katkı maddesi oranının 7 ve 28 gün kür süreleri için XRD grafiğindeki etkisini göstermektedir. Şekil 12'de düşük oranlardaki kirecin (\%2) 7 gün için mineralojik açıdan önemli bir etkiye sahip olmadığını göstermektedir. Bunun yanında \%4 ve $\% 8$ kireç oranları zeminin mineralojisinde az da olsa etkili olabilmiștir. Öte yandan, 28 gün kür süresine sahip örneklerin grafiklerinde özellikle \%8 kireç içeriği için yeni kırınımlar gözlenmiştir. $\mathrm{Bu}$ sonuca göre tarama malzemesinde mineralojik açıdan değişimlerin 28 günden sonra bașladığı söylenebilir.

Şekil 13 kireç içeriğindeki artışa bağlı olarak kırınımlardaki artan şiddeti de göstermektedir. Yeni kırınımlar ve artan şiddetler göz önüne alındığında kireç ile tarama malzemesi arasında kireç içeriğine bağlı olarak artan bir oranda reaksiyonların gerçekleştiği söylenebilir. Aynı durum kür süresi içinde geçerlidir. Aynı oranda kireç içeriğine sahip örnekler karşılaştırıldığında (Şekil 12-13) kür süresi uzadığında kırınımlarda ve kırınımların şiddetlerinde artışlar gözlenmektedir.

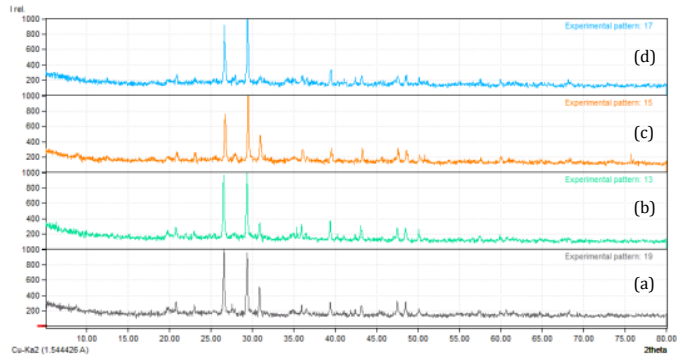

Şekil 12. İşlenmemiş (a), \%2 kireç (b), \%4 kireç (c) ve \%8 kireç ile iyileștirilmiş zeminin 7 gün sonunda X-ıșını kırınım grafikleri

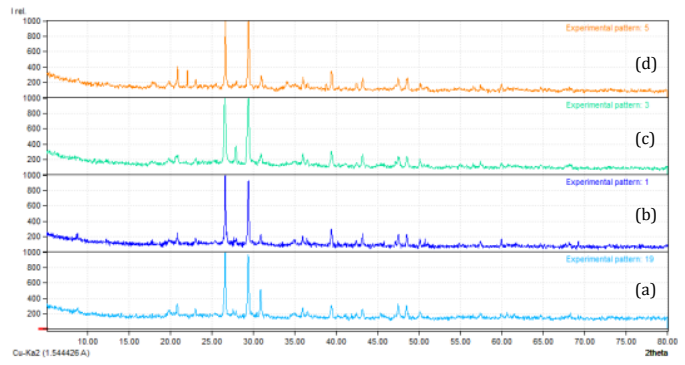

Şekil 13. İşlenmemiş (a), \%2 kireç (b), \%4 kireç (c) ve $\% 8$ kireç ile iyileştirilmiş zeminin 28 gün sonunda X-ıșını kırınım grafikleri

Zayıf Meles Deltası zeminlerinin XRD deney sonuçları stabilizasyonun genel olarak mineralojik değişimlerden bağımsız olduğunu 
göstermektedir. Dayanımdaki artıșın kirecin hidrate olurken zemin bünyesinden aldığı su ile katılaşması ve zemin danelerinin birlerine bağlanması neticesinde dane boyutunun artması neticesinde geliștiği kanaatine varılmıștır.

Şekil 14 ve 15 değişik kireç-çimento oranlarına karşılık tarama malzemesinin XRD grafiklerini göstermektedir. Sadece kireçli karışımlara ters bir şekilde çimento-kireç karışımları zemin mineralojik yapısında önemli değișikliklere neden olmuştur. Şekil 14'ye bakıldığında 7 gün kür süresine sahip örneklerde yeni kırınım pikleri görülebilir. Aynı durum Şekil 15'de 28 gün kür süresine sahip örnekler için aynı piklerde daha şiddetli olmuștur.

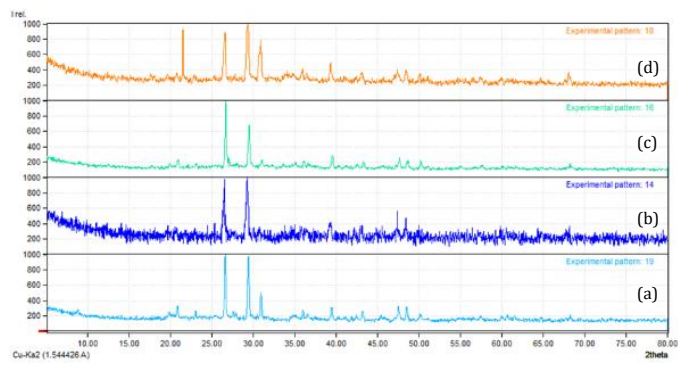

Şekil 14. İşlenmemiș (a), \%2 kireç + \%2 çimento (b), \%4 kireç + \%4 çimento (c) ve \%8 kireç + \%8 çimento ile iyileştirilmiş örneklerin

7 gün sonunda X-ışını kırınım grafikleri

Şekil 16 ve 17 kırınım örüntülerinden çok 28 gün kür süresine sahip örneklerde reaksiyon ürünlerinin tespiti için incelenmiştir. Şekil 16 \%8 kireç ile iyileștirilmiş Meles Deltası zeminlerinin kırınım grafiğini göstermektedir.

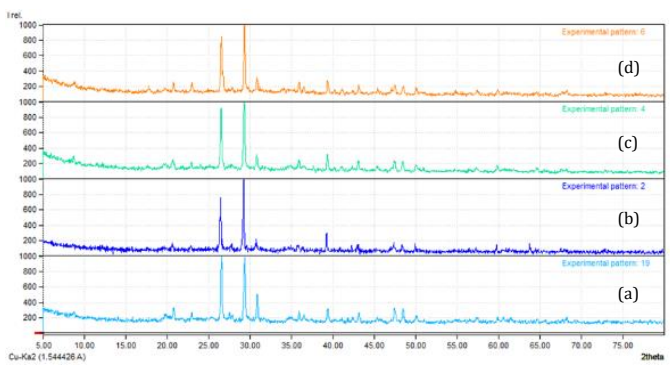

Şekil 15. İşlenmemiș (a), \%2 kireç + \%2 çimento (b), \%4 kireç + \%4 çimento (c) ve \%8 kireç $+\% 8$ çimento ile iyileștirilmiș örneklerin

28 gün sonunda X-ıșını kırınım grafikleri

$\mathrm{Bu}$ şekilde, dikkate değer bir șekilde kalsiyum karbonat kırınımı belirlenmiştir. Bu durumun büyük bir olasılıkla kirecin örneğin kalıplanması sırasında atmosfer ile teması sonucu karbonatlaşması ile oluştuğu düşünülmektedir.

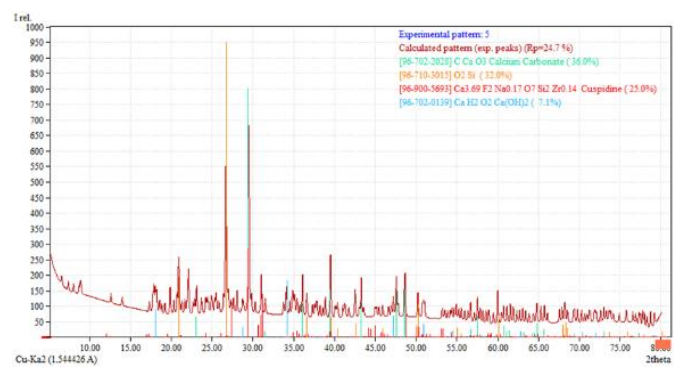

Sekil 16. \%8 kireç ile iyileștirilmiș zeminin 28 gün sonunda X-ışını kırınım grafikleri

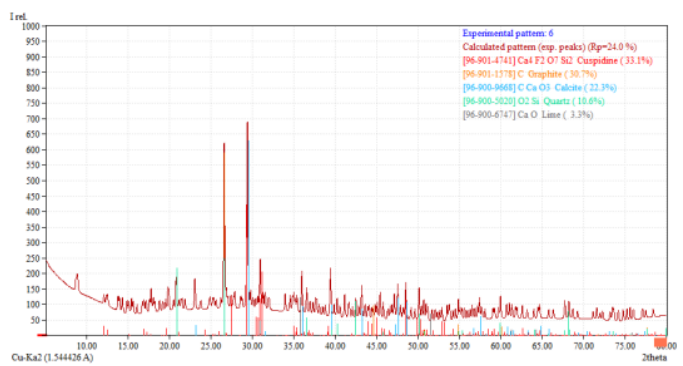

Şekil 17. $\% 8$ kireç ve $\% 8$ çimento ile iyileştirilmiş zeminin 28 gün sonunda X-ışını kırınım grafikleri

Karbonatlașma ürünleri $\% 8$ kireç ve $\% 8$ çimento kullanılarak iyileștirilen tarama malzemesinde de Şekil 17'de gösterildiği șekilde bulgulanmıștır. Çimentonun da eklenmesi ile $\mathrm{CSH}$ ve CAH oluşumlarının sadece kireç ile iyileștirilen tarama malzemesine göre daha belirgin olduğu görülmüștür. Ancak Şekil 17'de az miktar kireç kırınımı da belirlenmiştir. Bu durum çimento katkısı ile kireç ve tarama malzemesi arasındaki reaksiyonun hızının azalması olarak yorumlanmıștır. Bu gözlem Lasledj ve Al-Mukhtar'ın [23] gerçekleştirdiği çalıșma ile benzerlik göstermektedir.

\section{Sonuçlar}

$\mathrm{Bu}$ çalışma kapsamında İzmir Körfez bölgesi doğu klyı şeridi delta zeminlerinden örnekler alınmış, laboratuvarda farklı kireç ve çimento oranları ile yerinde yapılacak derin karıștırma uygulaması ile uyumlu olacak şekilde örnekler hazırlanmış ve bu örnekler üzerinde tek eksenli basınç deneyleri ve XRD ve SEM analizleri gerçekleștirilmiştir. $\mathrm{Bu}$ makalede farklı oranlarda kireç ve çimento katkısının zemin yapısını nasıl etkilediği XRD ve SEM analizleri ile ortaya koyulmaya çalışılmıştır. Çalışma neticesinde şu sonuçlara ulaşılmıştır:

- Elde edilen SEM görüntülerine bakıldığında, iyileşmiş zeminlerin homojen bloklardan 
DEU FMD 21(63), 967-978, 2019

oluştuğu görülmüştür. $\mathrm{Bu}$ da çalışmada kullanılan örnek oluşturma tekniğinin başarılı olduğunu göstermektedir. Bir başka önemli nokta ise çimentolanma reaksiyonları için gerekli nemin örneklerin suya batık olarak kür edilmesi ile karșılandığı ve bu süreçte yerleştirilen filtre kağıtlarının önemli bir işlevi olduğudur.

- $\mathrm{Bu}$ çalışmadaki bir başka sonuç ise SEM görüntüleri ile dayanım deneylerinden elde edilen sonuçların paralellik gösterdiğidir. Karışım oranı ve kür süresine bağlı olarak yüksek dayanıma sahip örneklerde hidrasyon reaksiyonları sonucu oluşan bileşenlere daha fazla rastlanmıştır.

- Yüksek \%4 kireç + \%4 çimento ve $\% 8$ kireç + $\% 8$ çimento gibi yüksek oranda katkı maddesi içeren numunelerde iğnemsi formlarda çimentolanma ürünlerine rastlanmış ve bu bulgu tek eksenli basınç deney sonuçları ile desteklenmiştir.

- İyileştirilmiş zeminlerdeki jel formdaki CSH ve CAH oluşumları ve CSH kristalleri SEM görüntülerinde açlkça görülmüș ve bu oluşumların bağlayıcı oranı arttıkça artış gösterdiği belirlenmiștir.

- XRD deney sonuçlarına göre, tarama malzemesinde mineralojik açıdan değişimlerin 28 günden sonra başladığı belirlenmiştir.

- Zayıf Meles Deltası zeminlerinin XRD deney sonuçları stabilizasyonun genel olarak mineralojik değișimlerden bağımsız olduğunu göstermiștir. Dayanımdaki artıșın kirecin hidrate olurken zemin bünyesinden aldığı su ile katılaşması ve zemin danelerinin birlerine bağlanması neticesinde agrega boyutunun artması neticesinde geliştiği kanaatine varılmıştır.

- Çalışma delta zeminlerinin kimyasal bağlayıcılar ile önemli oranda stabilize edilebileceğini kanıtlamıştır. Optimum bağlayıcı yüzdesi ve çeșiti, bölgede planlanan yapıların zemine aktaracağı gerilmelere bağlı olmakla beraber, tek eksenli basınç deneyleri, SEM ve XRD analizleri beraber değerlendirildiğinde \%4 kireç ve \%4 çimento katkısının önerilebileceği sonucuna varılmıștır.

\section{Teșekkür}

Bu çalışma Doç.Dr. Ali Hakan Ören yürütücülügündeki 111M718 numaralı Tübitak projesi tarafından sağlanan ekipman ve finans desteği ile gerçekleştirilmiștir.

\section{Kaynakça}

[1] Bruce, D.A., Bruce, M.E.C. and Dimillio, A.F., 1999. Dry mix methods: A brief overview of international practice. In Proceedings of International Conference on Dry Mix Methods for Deep Soil Stabilization, Balkema, Rotterdam (pp. 15-25).

[2] Timoney, M.J. and McCabe, B., 2012. Experiences of dry soil mixing in organic soils. Journal of Engineering Geology, 19(1), pp.7-80.

[3] Baran, T. ve Gülay, M. İzmir Meles Çayı Deltası Islah projesi, Türkiye İnşaat Mühendisliği XVII. Teknik Kongre ve Sergisi, TMMOB İnşaat Mühendisleri Odası, 14 - 17 Nisan 2004, İstanbul.

[4] Locat, J., Bérubé, M.A. and Choquette, M., 1990. Laboratory investigations on the lime stabilization of sensitive clays: shear strength development. Canadian Geotechnical Journal, 27(3), pp.294-304.

[5] Bell, F.G., 1996. Lime stabilization of clay minerals and soils. Engineering geology, 42(4), pp.223-237.

[6] Prusinski, J. and Bhattacharja, S., 1999. Effectiveness of Portland cement and lime in stabilizing clay soils. Transportation Research Record: Journal of the Transportation Research Board, (1652), pp.215-227.

[7] Esrig, M.I., Mac Kenna, P.E. and Forte, E.P., 2003. Ground stabilization in the United States by the Scandinavian lime cement dry mix process. In Grouting and Ground Treatment (pp. 501-514).

[8] Rajasekaran, G., 2005. Sulphate attack and ettringite formation in the lime and cement stabilized marine clays. Ocean Engineering, 32(8-9), pp.1133-1159.

[9] Boardman, D.I., Glendinning, S. and Rogers, C.D.F., 2001. Development of stabilisation and solidification in lime-clay mixes. Geotechnique, 51(6), pp.533543.

[10] Bergado, D.T., Anderson, L.R., Miura, N. and Balasubramaniam, A.S., 1996, January. Soft ground improvement in lowland and other environments. ASCE.

[11] Hebib, S. and Farrell, E.R., 2003. Some experiences on the stabilization of Irish peats. Canadian geotechnical journal, 40(1), pp.107-120.

[12] Hernandez-Martinez, F.G., \& Al Tabbaa, A. (2005). Strength properties of stabilised peat. Proceedings of the International Conference on Deep Mixing - Best Practice and Recent Advances. Swedish Deep Stabilisation Research Centre, Stockholm, Sweden, (1), 69-78.

[13] Axelsson, K., Johansson, S.E. and Andersson, R., 2002. Stabilization of organic soils by cement and Puzzolanic reactions-feasibility study. Swedish Deep Stabilization Research Centre, Report, 3, pp.1-51.

[14] Wang, D., Abriak, N.E., Zentar, R. and Chen, W., 2013. Effect of lime treatment on geotechnical properties of Dunkirk sediments in France. Road Materials and Pavement Design, 14(3), pp.485-503.

[15] Grubb, D.G., Chrysochoou, M., Smith, C.J. and Malasavage, N.E., 2010. Stabilized dredged material. I: Parametric study. Journal of Geotechnical and Geoenvironmental Engineering, 136(8), pp.10111024. 
DEU FMD 21(63), 967-978, 2019

[16] Miura, N., Horpibulsuk, S. and Nagaraj, T.S., 2001. Engineering behavior of cement stabilized clay at high water content. Soils and Foundations, 41(5), pp.33-45.

[17] Di Sante, M., Fratalocchi, E., Mazzieri, F. and Pasqualini, E., 2014. Time of reactions in a lime treated clayey soil and influence of curing conditions on its microstructure and behaviour. Applied Clay Science, 99, pp.100-109.

[18] Rajasekaran, G., Murali, K. and Srinivasaraghavan, R., 1997. Fabric and mineralogical studies on lime treated marine clays. Ocean engineering, 24(3), pp.227-234.

[19] Dash, S.K. and Hussain, M., 2011. Lime stabilization of soils: reappraisal. Journal of materials in civil engineering, 24(6), pp.707-714.

[20] Jose, B.T. (1989). A study of the physical and engineering behaviour of Cochin marine clays. Ph.D. Thesis, Cochin University of Science and Technology, Cochin.

[21] LADES, J. and GRIM, R., 1966. A quick test to determine lime requirements of lime stabilisation. Highway Research Record, 139, pp.61-72.

[22] Sarıavcı, C., (2016). Stabilizing Meles Delta Soils and Monitoring the Bonding Structures Using SEM and XRD Analyses. Dokuz Eylül University Graduate School of Natural and Applied Sciences. Master Thesis.

[23] Lasledj, A. and Al-Mukhtar, M., 2008, October. Effect of hydrated lime on the engineering behaviour and the microstructure of highly expansive clay. In The 12th International Conference of International Association for Computer Methods and Advances in Geomechanics. 